\title{
РЕСВЕРАТРОЛ ЯК ЗАСІБ ЦИТОПРОТЕКТОРНОЇ ДІЇ ЗА УМОВ ІНДУКОВАНОГО КАНЦЕРОГЕНЕЗУ В ЩУРІВ
}

Вступ. Важливим фундаментальним завданням сучасних експериментальних і клінічних досліджень в онкології є вивчення існуючих та виявлення нових, у тому числі метаболічних, чинників, які сприяють виникненню і прогресуванню пухлинного процесу. Дослідження in vitro ma in vivo показали, що фрітохімічні речовини мають потенційні антиоксидантні, протизапальні та антиканцерогенні властивості. На сьогодні активно вивчають механізми протиракової активності ресвератролу - природного поліфренолу, який здатний інгібувати проліфрерацію більшості клітинних ліній раку людини.

Мета дослідження - вивчити цитопротекторні властивості ресвератролу за умов індукованого диметилгідразином онкопроцесу.

Методи дослідження. Експерименти виконано на білих щурах-самцях, яким моделювали рак товстої кишки шляхом щотижневого підшкірного введення диметилгідразину в дозі 7,2 мг/кг маси тіла впродовж 30 тижнів. Антиоксидант ресвератрол вводили інтрагастрально в дозі 20 мг/кг щоденно протягом 7 місяців. Стан цитоплазматичних клітинних мембран вивчали за активністю гамма-глутамілтранспептидази та лужної фросфратази. Ступінь ендотоксемії оцінювали шляхом визначення еритроцитарного індексу інтоксикації та вмісту молекул середньої маси.

Результати й обговорення. Після введення щурам диметилгідразину спостерігали підвищення у сироватці крові активності гамма-глутамілтранспептидази та лужної фоссратази в усі терміни дослідження, а також ї̈ зниження в печінці тварин з канцерогенезом. На тлі щоденного застосування ресвератролу активність гамма-глутамілтранспептидази зменшилась у 2 рази, лужної фросфратази - у 2,3 раза щодо тварин, яким вводили диметилгідразин. У щурів, які отримували антиоксидант ресвератрол, проникність еритроцитарної мембрани зменшилась на 50,7 \% порівняно з тваринами, які його не одержували. Використання ресвератролу призвело до зменшення у сироватці крові вмісту молекул середньої маси всіх фрракцій, що вказує на зниження проявів ендогенної інтоксикації в ураженому організмі.

Висновки. Отримані результати підтверджують цитопротекторні властивості ресвератролу, на які вказує відновлення активності мембранозалежних ензимів у щурів з експериментальним канцерогенезом. Доведено, що за цих умов проорілактичне застосування ресвератролу знижує рівень ендогенної інтоксикації та сприяє відновленню проникності еритроцитарних мембран, що підтверджує його мембранопротекторні властивості.

КЛЮЧОВІ СЛОВА: цитолітичні процеси; ендогенна інтоксикація; проникність клітинних мембран; ресвератрол.

ВСТУП. У структурі злоякісних пухлин шлунково-кишкового тракту колоректальний рак перебуває на третьому місці за частотою захворюваності та на другому - за рівнем смертності. За даними ВООЗ, кожного року реєструють 500 тис. випадків раку товстої кишки [1].

У літературі є повідомлення про те, що значна частина онкохворих гине від розвитку цитолітичних процесів і так званої ендогенної інтоксикації. Вивчення цього питання за умов індукованого канцерогенезу є одним із перспективних, оскільки онкопроцес супроводжується посиленням процесів катаболізму в тканинах з утворенням нових токсичних продуктів [2], які можуть деструктивно впливати на клітинні мембрани. (с) О. Б. Рицик, Л. С. Фіра, П. Г. Лихацький, 2021.
Існує значна кількість експериментальних моделей ініціації пухлинного росту в різних органах. Для оцінки гістологічних та біохімічних особливостей розвитку пухлин широко використовують модель раку кишечника щурів, індукованого диметилгідразином (ДМГ), що зумовлено його морфологічною подібністю до колоректального раку людини [3]. Диметилгідразин $€$ непрямим специорічним канцерогеном і викликає ініціацію та розвиток раку товстої кишки дозозалежним способом [4].

На сучасному етапі розвитку онкологічної науки та практики сумісне призначення кількох лікарських засобів досить часто $є$ необхідним у зв'язку з наявністю множинної патології і множинних симптомів, а також потребою додатко- 
вого лікування та/або профілактики побічних есректів й ускладнень протиракової терапії, що підвищує сумарний ризик виникнення несприятливих реакцій [5]. Саме тому пошук нових високоефективних біологічно активних речовин природного походження $є$ одним 3 основних напрямів розробки лікарських засобів для лікування захворювань різної етіології.

Протягом останніх років усе більшу увагу до себе привертає ресвератрол (транс-3,5,40-тригідроксистилбен) - стильбеноїд, природний полісенол, фрітоалексин, який має ряд переваг перед іншими природними антиоксидантами, включаючи кардіопротекцію та профрілактику раку [6].

На сьогодні активно вивчають механізми протиракової активності ресвератролу [7]. Він проявив здатність інгібувати проліферацію більшості клітинних ліній раку людини, включаючи рак грудної залози, простати, шлунка, товстої кишки, підшлункової та щитоподібної залоз.

Широкий спектр фрармакологічної активності ресвератролу зумовлює його подальше дослідження, зокрема за умов активного розвитку онкопроцесу.

У зв'язку з цим, всебічне патогенетичне обґрунтування використання антиоксидантів рослинного походження при неопластичній інтоксикації $€$ доцільним і перспективним напрямом розробки схем лікування та профілактики для онкохворих.

Мета дослідження - вивчити цитопротекторні властивості ресвератролу за умов індукованого диметилгідразином онкопроцесу.

МЕТОДИ ДОСЛІДЖЕННЯ. Для досліджень використовували білих безпородних щурів-самців, яких утримували на стандартному раціоні віварію Тернопільського національного медичного університету імені І. Я. Горбачевського МОЗ України. Маса тіла тварин становила 180-220 г. Щурів було поділено на 3 групи: 1-ша інтактний контроль; 2-га - тварини, яким моделювали хронічну неопластичну інтоксикацію; 3-тя - тварини, яким моделювали хронічну неопластичну інтоксикацію та щоденно вводили антиоксидант ресвератрол.

Хронічну неопластичну інтоксикацію моделювали шляхом введення несиметричного диметилгідразину (фрірми "SIGMA-ALDRICH CHEMIE", виробництва Японії), попередньо розведеного ізотонічним розчином натрію хлориду. Канцероген вводили підшкірно в міжлопаткову ділянку в дозі 7,2 мг/кг (з розрахунку на діючу речовину) 1 раз на тиждень упродовж 30 тижнів відповідно до маси тварини [8]. Конт- ролем для групи тварин, яким вводили ДМГ, були щури, яким щотижня підшкірно вводили 0,1 мл фрізіологічного розчину на 100 г маси тіла.

3 метою корекції виявлених порушень тваринам однієї з груп внутрішньошлунково вводили препарат "Ресверазин" (ТОВ "Нутрімед", Україна) в дозі 20 мг/кг (з розрахунку на діючу речовину). Перерахунок проводили, виходячи із середньотерапевтичної дози та беручи до уваги видову чутливість тварин за Ю. Р. Риболовлєвим [9].

Кожного місяця від початку дослідження уражених та лікованих тварин виводили з експерименту шляхом евтаназії під тіопенталовим наркозом.

Для дослідження брали цільну кров, сироватку крові та печінку тварин.

Стан цитоплазматичних клітинних мембран вивчали за активністю гамма-глутамілтранспептидази (ГГТП) [10] та лужної фоосфатази (ЛФ) [11] у досліджуваних тканинах. Ступінь ендотоксемії оцінювали шляхом визначення еритроцитарного індексу інтоксикації (EII) за методом А. А. Тогайбаєва [12] та вмістом молекул середньої маси (MCM) шляхом осадження протеїнів трихлороцтовою кислотою [13].

При проведенні досліджень користувались загальними принципами експериментів на тваринах, узгодженими 3 положеннями Європейської конвенції про захист хребетних тварин, що використовуються для дослідних та інших наукових цілей [14].

Результати досліджень піддавали статистичному аналізу [15] за допомогою статистичної програми STATISTICA 6.0 з використанням параметричного критерію Стьюдента і непараметричного критерію Вілкоксона для зв'язаних вибірок. Зміни вважали вірогідними при p $\leq 0,05$.

РЕЗУЛЬТАТИЙ ОБГОВОРЕННЯ. ВіДОМО, ЩО розвиток пухлинного процесу супроводжується порушеннями окисно-відновної рівноваги. Значну роль тут відіграють активні фрорми оксигену, що призводить до активації процесів вільнорадикального окиснення та, у свою чергу, викликає руйнування клітинних мембран [16, 17].

Ми вивчили активність ГГТП - ензиму, який локалізується в основному на рівні цитоплазматичних мембран клітин, що вистилають порожнини із секреторною та адсорбуючою функціями [18]. За умов ДМГ-індукованого канцерогенезу спостерігали збільшення активності цього ензиму в сироватці крові в усі терміни експерименту. На 7-й місяць дослідження даний показник підвищився, порівняно з групою інтактного контролю, у 2,3 раза. У гомогенаті печінки відзначали зменшення активності ГГТП, і на 7-му місяці вона 
була вдвічі нижчою, ніж у групі інтактного контролю (табл. 1).

На тлі застосування ресвератролу активність ГГТП у сироватці крові була нижчою на 120 \% у відповідний термін дослідження порівняно 3 показником у тварин, яким корекції не проводили. Щодо динаміки в печінці щурів після використання цього антиоксиданта, то активність ГГТП зростала і була вищою, ніж в уражених ДМГ тварин, на 52,2 \% на 7-му місяці експерименту.

Паралельно у сироватці крові та печінці піддослідних тварин вивчали активність ЛФ - органоспецисрічного ензиму, одного 3 маркерів холестазу, що також свідчить про ушкодження мембран гепатоцитів.

Рівень ЛФ у сироватці крові використовують для клінічної оцінки численних захворювань, включаючи злоякісні пухлини, протягом півстоліття. Встановлено, що підвищений передопераційний рівень ЛФ був пов'язаний не тільки із захворюваннями печінки, але також із розвинутим статусом пухлини, і свідчив про незначну виживаність хворих на рак товстої кишки та прямої кишки [19].

При неопластичному ендотоксикозі спостерігали підвищення активності ЛФ у сироватці крові в усі терміни дослідження (табл. 2).

Активність ензиму до кінця дослідження (7-й місяць розвитку аденокарциноми товстої кишки) становила 235 \% щодо тварин групи інтактного контролю.

Однією 3 найпоширеніших причин високої активності ЛФ у сироватці крові може бути, на нашу думку, розвиток запальних процесів у печінці.

Після використання препарату “Ресверазин" активність ЛФ у сироватці крові була нижчою на 84, 116, 134 \% відповідно в терміни 3-й, 5-й, 7-й місяці дослідження порівняно з показником у тварин, яким корекції не проводили (рис. 1).

У печінці тварин, уражених ДМГ, відзначали зниження активності ензиму в усі терміни проведеного експерименту: на 3-й місяць вона була на 29,5 \% меншою порівняно з тваринами інтактного контролю, на 5-й-на 50,3\%, на 7-й-на 64,4 \%.

Підвищення активності лужної фоосратази у сироватці крові та зниження в гомогенаті печінки вказують, очевидно, на застій жовчі у жовчних протоках, оскільки порушення відтоку жовчі посилює потрапляння цього ензиму в кровообіг.

Використання ресвератролу зумовило нормалізацію активності ЛФ у гомогенаті печінки. Активність досліджуваного ензиму була вищою на 10,4, 39,3 і 65,0 \% у відповідні терміни дослідження порівняно $з$ показником у тварин, яким корекції не проводили.

Поряд зі змінами проникності мембран гепатоцитів ми спостерігали зміну проникності ерит-

Таблиця 1 - Активність гамма-глутамілтранспептидази у сироватці крові та печінці щурів

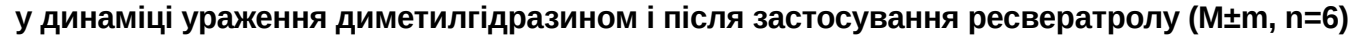

\begin{tabular}{|c|c|c|c|c|}
\hline \multirow{2}{*}{ Група тварин } & \multicolumn{2}{|c|}{ "Сироватка крові, мккат/л } & \multicolumn{2}{|c|}{ "Печінка, мккат/кг } \\
\hline & ДМГ & ДМГ+ресвератрол & ДМГ & ДМГ+ресвератрол \\
\hline Інтактний контроль & \multicolumn{2}{|c|}{$0,85 \pm 0,02$} & \multicolumn{2}{|c|}{$1,13 \pm 0,03$} \\
\hline 1-й місяць & $0,97 \pm 0,02^{*}$ & $0,90 \pm 0,015$ & $0,99 \pm 0,04^{*}$ & $1,12 \pm 0,03$ \\
\hline 2-й місяць & $1,18 \pm 0,02^{*}$ & $1,15 \pm 0,015$ & $0,89 \pm 0,02^{*}$ & $0,93 \pm 0,01$ \\
\hline 3-й місяць & $1,21 \pm 0,02^{*}$ & $1,14 \pm 0,011^{\star \star}$ & $0,79 \pm 0,03^{*}$ & $0,94 \pm 0,02^{\star \star}$ \\
\hline 4-й місяць & $1,36 \pm 0,03^{*}$ & $1,11+0,03^{\star \star}$ & $0,69 \pm 0,03^{*}$ & $1,01 \pm 0,02^{\star \star}$ \\
\hline 5-й місяць & $1,74 \pm 0,04^{*}$ & $1,05 \pm 0,03^{\star *}$ & $0,64 \pm 0,02^{*}$ & $1,03 \pm 0,03^{\star *}$ \\
\hline 6-й місяць & $1,88 \pm 0,02^{\star}$ & $0,97 \pm 0,03^{\star \star}$ & $0,54 \pm 0,02^{*}$ & $1,09 \pm 0,03^{\star \star}$ \\
\hline 7-й місяць & $1,96 \pm 0,03^{*}$ & $0,94 \pm 0,02^{* *}$ & $0,57 \pm 0,02^{*}$ & $1,16 \pm 0,02^{\star *}$ \\
\hline
\end{tabular}

Примітка. Тут і в таблицях 2, 3: * - вірогідні зміни між показниками тварин групи інтактного контролю та щурів, ура-

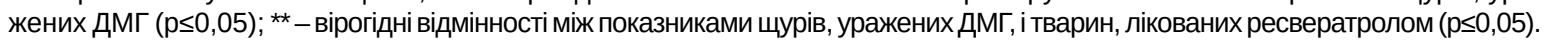

Таблиця 2 - Активність лужної фосфатази у сироватці крові та печінці щурів у динаміці ураження диметилгідразином і після застосування ресвератролу $(\mathrm{M} \pm \mathrm{m}, \mathrm{n}=6)$

\begin{tabular}{|c|c|c|c|c|}
\hline \multirow{2}{*}{ Група тварин } & \multicolumn{2}{|c|}{ Сироватка крові, мккат/л } & \multicolumn{2}{|c|}{ Печінка, мккат/кг } \\
\hline & ДМГ & ДМГ+ресвератрол & ДМГ & ДМГ+ресвератрол \\
\hline Інтактний контроль & \multicolumn{2}{|c|}{$2,08 \pm 0,08$} & \multicolumn{2}{|c|}{$1,63 \pm 0,04$} \\
\hline 1-й місяць & $3,12 \pm 0,12^{*}$ & $2,19 \pm 0,06^{\star \star}$ & $1,31 \pm 0,04^{*}$ & $1,46 \pm 0,03^{\star \star}$ \\
\hline 2-й місяць & $4,71 \pm 0,13^{*}$ & $2,48 \pm 0,05^{\star \star}$ & $1,27 \pm 0,02^{*}$ & $1,39 \pm 0,02^{\star \star}$ \\
\hline 3-й місяць & $4,48 \pm 0,19^{*}$ & $2,73 \pm 0,06^{\star \star}$ & $1,15 \pm 0,03^{*}$ & $1,32 \pm 0,04^{\star \star}$ \\
\hline 4-й місяць & $4,34 \pm 0,16^{*}$ & $2,57 \pm 0,03^{\star \star}$ & $0,96 \pm 0,05^{\star}$ & $1,37 \pm 0,03^{\star \star}$ \\
\hline 5-й місяць & $4,81 \pm 0,14^{*}$ & $2,40 \pm 0,03^{\star \star}$ & $0,81 \pm 0,04^{*}$ & $1,45 \pm 0,02^{\star \star}$ \\
\hline 6-й місяць & $4,82 \pm 0,08^{\star}$ & $2,28 \pm 0,05^{\star \star}$ & $0,70 \pm 0,04^{\star}$ & $1,53 \pm 0,03^{\star \star}$ \\
\hline 7-й місяць & $4,88 \pm 0,06^{*}$ & $2,11 \pm 0,05^{\star *}$ & $0,58 \pm 0,05^{\star}$ & $1,64 \pm 0,04^{\star *}$ \\
\hline
\end{tabular}




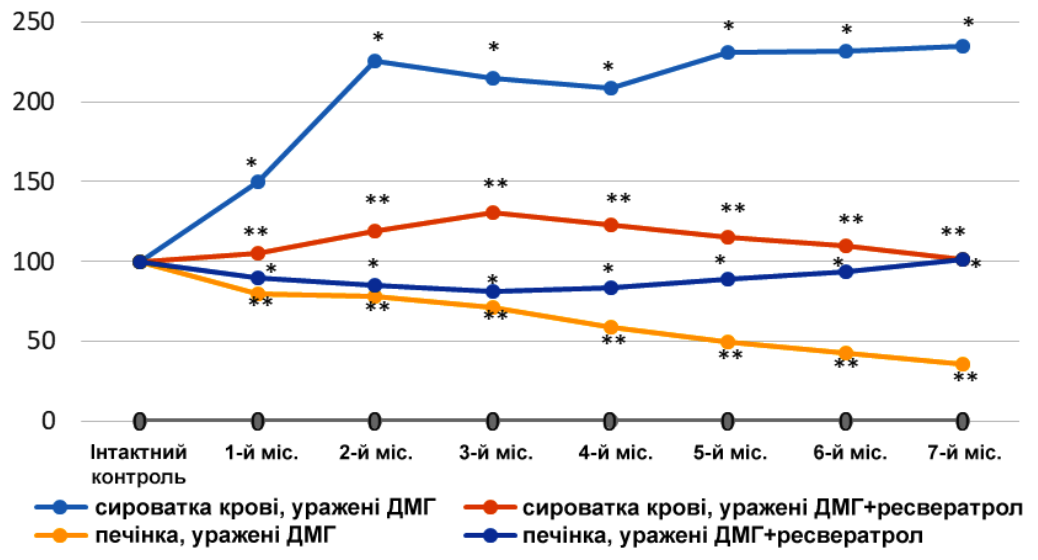

Рис. 1. Динаміка активності лужної фросфратази у сироватці крові та печінці щурів при ДМГ-індукованому канцерогенезі й після застосування ресвератролу, \%.

Примітка. Тут і на рисунку 2: * - вірогідні зміни між показниками тварин групи інтактного контролю та щурів, уражених ДМГ ( $\mathrm{p} \leq 0,05)$; ${ }^{* *}$ - вірогідні відмінності між показниками щурів, уражених ДМГ, і тварин, лікованих ресвератролом $(p \leq 0,05)$.

роцитарної мембрани, підтвердженням чого було збільшення відсотка EII (рис. 2). Так, він був вищим в уражених щурів, ніж у тварин групи інтактного контролю: на 3-му місяці експерименту - на 27,4 \%, на 5-му - на 55,2 \%, на 7-му - на $65,9 \%$. Застосований коригувальний чинник зумовив зменшення EII (на 7-му місяці він був нижчим на 50,7 \% порівняно з тваринами, яким корекції не проводили), що свідчить про стабілізацію проникності мембран еритроцитів.

Отже, з подовженням терміну дослідження відмічають прогресуюче збільшення проникності еритроцитарної мембрани, що підтверджує токсичну дію ДМГ на кров. Застосування ресвератролу, очевидно, через прояв антиоксидантних властивостей, зумовлює відновлення проникності плазматичної мембрани еритроцитів, що може вказувати на його мембранопротекторні властивості.

Синдром ендогенної інтоксикації належить до найбільш поширених у клінічній практиці й виникає при найрізноманітніших етіологічно та патогенетично неоднорідних станах $[20,21]$.

Клінічні прояви синдрому ендогенної інтоксикації малоспецифічні, тому важливу роль у діаг- ностиці ендотоксикозу відіграють лабораторні дослідження [22].

Накопичення МСМ розглядають не лише як маркер ендогенної інтоксикації, в подальшому вони можуть посилювати перебіг патологічного процесу (набуваючи ролі вторинних токсинів) i, таким чином, впливають на фукціонування всіх органів та систем [13].

За умов змодельованої неопластичної інтоксикації спостерігали зростання вмісту всіх фрракцій $\mathrm{MCM}_{1}$ як маркерів ендотоксикозу (табл. 3). Так, вміст $\mathrm{MCM}_{238}$ був більшим порівняно 3 тваринами групи інтактного контролю: на 3-й місяць - на 33,9 \%, на 5-й - на 42,7 \%, на 7-й - на 62,1 \%. Аналогічне підвищення показника відзначали для фрракції $\mathrm{MCM}_{254}$ : на 3-й місяць ураження - на 75,5 \%, на 5-й - на 93,6 \%, на 7-й - на 117,0 \%, що може свідчити про посилений катаболізм протеїнів і метаболітів з низькою молекулярною масою.

Подібну тенденцію до зростання відмічали й у фрракціях $\mathrm{MCM}_{2}$ (табл. 3). Вміст $\mathrm{MCM}_{260}$ збільшувався в усі терміни дослідження і наприкінці експерименту був на 71,5 \% вищим від контролю. Зростав і вміст $\mathrm{MCM}_{280}$ : на 3-й місяць моделю-

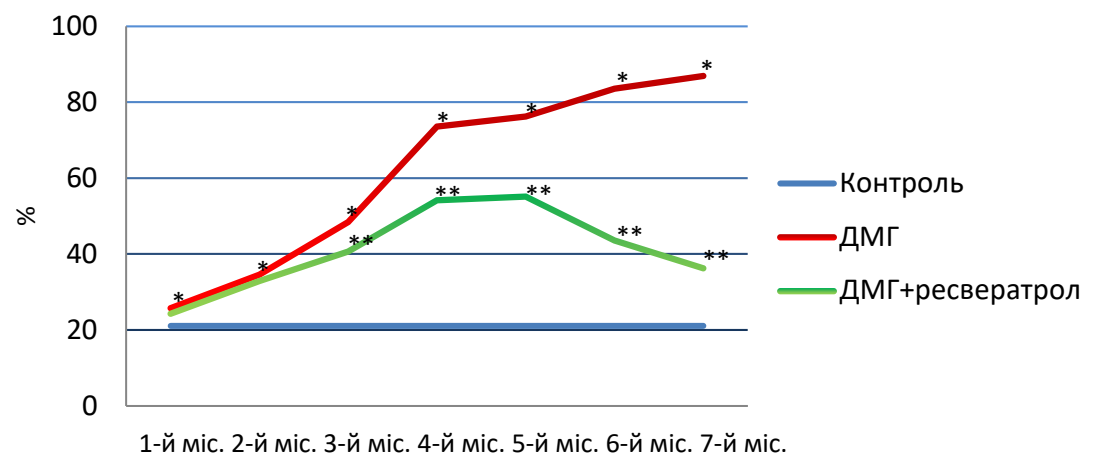

Рис. 2. Еритроцитарний індекс інтоксикації у крові щурів у динаміці ураження диметилгідразином і після застосування ресвератролу, \% 
Таблиця 3 - Вміст молекул середньої маси у сироватці крові щурів, уражених диметилгідразином, і після застосування ресвератролу (M $\pm m, n=6)$

\begin{tabular}{|c|c|c|c|c|}
\hline $\begin{array}{c}\text { Група } \\
\text { тварин } \\
\end{array}$ & $\mathrm{MCM}_{238}$, ОД/л & $\mathrm{MCM}_{254}$, ОД/л & $\mathrm{MCM}_{260}$, ОД/л & $\mathrm{MCM}_{280}$, ОД/л \\
\hline Інтактний контроль & $0,103 \pm 0,007$ & $0,094 \pm 0,003$ & $0,102 \pm 0,006$ & $0,099 \pm 0,006$ \\
\hline 1-й місяць ДМГ & $0,132 \pm 0,007^{*}$ & $0,115 \pm 0,006^{*}$ & $0,106 \pm 0,005$ & $0,111 \pm 0,008$ \\
\hline ДМГ+ресвератрол & $0,107 \pm 0,006^{\star \star}$ & $0,101 \pm 0,004$ & $0,103 \pm 0,004$ & $0,108 \pm 0,006$ \\
\hline 2-й місяць ДМГ & $0,154 \pm 0,006^{*}$ & $0,153 \pm 0,010^{*}$ & $0,163 \pm 0,010^{*}$ & $0,170 \pm 0,010^{*}$ \\
\hline ДМГ+ресвератрол & $0,123 \pm 0,007^{\star \star}$ & $0,116 \pm 0,007^{\star \star}$ & $0,116 \pm 0,007^{\star \star}$ & $0,121 \pm 0,005^{\star \star}$ \\
\hline 3-й місяць ДМГ & $0,138 \pm 0,008^{\star}$ & $0,165 \pm 0,010^{\star}$ & $0,149 \pm 0,007^{*}$ & $0,152 \pm 0,005^{\star}$ \\
\hline ДМГ+ресвератрол & $0,115 \pm 0,003^{\star \star}$ & $0,135 \pm 0,005^{\star \star}$ & $0,120 \pm 0,008^{\star \star}$ & $0,119 \pm 0,005^{\star \star}$ \\
\hline 4-й місяць ДМГ & $0,140 \pm 0,009^{\star}$ & $0,170 \pm 0,008^{\star}$ & $0,145 \pm 0,003^{*}$ & $0,163 \pm 0,011^{*}$ \\
\hline ДМГ+ресвератрол & $0,125 \pm 0,006$ & $0,132 \pm 0,006^{\star *}$ & $0,118 \pm 0,009$ ** & $0,127 \pm 0,005^{\star \star}$ \\
\hline 5-й місяць ДМГ & $0,147 \pm 0,008^{*}$ & $0,182 \pm 0,007^{*}$ & $0,153 \pm 0,008^{*}$ & $0,170 \pm 0,007^{*}$ \\
\hline ДМГ+ресвератрол & $0,118 \pm 0,007^{* *}$ & $0,125 \pm 0,009 * *$ & $0,122 \pm 0,007^{\star \star}$ & $0,116 \pm 0,008 * \star$ \\
\hline 6-й місяць ДМГ & $0,164 \pm 0,009^{*}$ & $0,194 \pm 0,006^{*}$ & $0,169 \pm 0,011^{*}$ & $0,175 \pm 0,021^{*}$ \\
\hline ДМГ+ресвератрол & $0,114 \pm 0,009^{* *}$ & $0,117 \pm 0,010^{\star *}$ & $0,119 \pm 0,009^{\star *}$ & $0,104 \pm 0,004^{\star *}$ \\
\hline 7-й місяць ДМГ & $0,166 \pm 0,007^{*}$ & $0,204 \pm 0,008^{\star}$ & $0,175 \pm 0,007^{*}$ & $0,204 \pm 0,008^{*}$ \\
\hline ДМГ+ресвератрол & $0,107 \pm 0,009 * \star$ & $0,108 \pm 0,008^{\star *}$ & $0,111 \pm 0,008^{\star *}$ & $0,108 \pm 0,008^{* *}$ \\
\hline
\end{tabular}

вання хронічної неопластичної інтоксикації - на 71,7 \%, на 7-й - на 106,1 \% щодо рівня контролю.

Однією з причин підвищення вмісту МСМ, можливо, є посилений протеоліз в ушкоджених тканинах, а також у самій сироватці крові при виході у кров протеолітичних ензимів. Утворені за цих умов гідрофобні токсини, зокрема продукти деградації протеїнів, вважають найбільш токсичними [20].

Застосування з коригувальною метою антиоксиданта ресвератролу зумовило вірогідне зниження $(p \leq 0,05)$ вмісту MCM усіх фрракцій (табл. 3).

Після використання препарату "Ресверазин" вміст MCM $_{238}$ був нижчим на 22,3\% через 3 місяці від початку введення ДМГ, на 28,1 \% - через 5 місяців, на 57,2 \% - через 7 місяців порівняно з групою тварин, які отримували тільки канцероген. Вміст $\mathrm{MCM}_{254}$ наприкінці дослідження був на $102,2 \%$, MCM $_{260}$ - на 63,77 \% меншим у тварин, які одержували коригувальний чинник, щодо уражених ДМг щурів. Аналогічну тенденцію

\section{СПИСОК ЛІТЕРАТУРИ}

1. Михайлович Ю. Й. Практичні аспекти впровадження скринінгу колоректального раку в Україні. Соціально-економічне обґрунтування / Ю. Й. Михайлович, А. В. Журбенко, О. В. Сумкіна // Клинич. онкология. - 2013. - № 3. - С. 6-10.

2. Вплив похідних дигідропіролу та малеіміду на стан печінки і товстої кишки щурів у нормі та в умовах індукованого диметилгідразином колоректального раку / Г. М. Кузнєцова, О. В. Линчак, М. О. Данилов [та ін.] // Укр. біохім. журн. - 2013. - № 85 (3). - С. 74-84. спостерігали у фрракції $\mathrm{MCM}_{280}$, їх вміст був нижчим на 33,3, 54,5, 97,0 \% проти щурів з експериментальним канцерогенезом у відповідні терміни дослідження.

ВИСНОВКИ. Результати проведених досліджень свідчать про те, що за умов тривалого введення диметилгідразину відбуваються поглиблення ендогенної інтоксикації організму і нагромадження значної кількості вторинних токсинів, які чинять деструктивний вплив на плазматичні мембрани, зокрема гепатоцитів та еритроцитів. Застосований із профрілактичною метою препарат "Ресверазин" зумовив зниження ступеня ендогенної інтоксикації та відновлення проникності клітинних мембран, на що вказує зменшення вмісту молекул середньої маси у сироватці крові й відсотка проникності еритроцитарної мембрани, а також зниження активності гамма-глутамілтранспептидази і лужної фросфратази у сироватці крові уражених диметилгідразином тварин.

3. Perse M. The dimethylhydrazine induced colorectal tumours in rat-experimental colorectal carcinogenesis / M. Perse, A. Cerar // Radiol. Oncol. -2005. -39, No 1. - P. 61-70.

4. Вплив похідного малеіміду на розвиток окисного стресу в печінці при індукованому 1,2-диметилгідразином канцерогенезі товстого кишечника щурів / О. М. Філінська, С. В. Яблонська, О. В. Линчак [та ін.] // Доп. Нац. акад. наук України. - 2010. - № 8. - С. 185190. 
5. Beijnen J. H. Drug interactions in oncology / J. H. Beijnen, J. H. Schellens // Lancet Oncol. - 2004. No. 5 (8). - P. 489-496.

6. Baur J. A. Therapeutic potential of resveratrol: the in vivo evidence / J. A. Baur, D. A. Sinclair // Nat. Rev. Drug Discov. - 2006. - 5. - P. 493-506.

7. Aziz M. H. Cancer chemoprevention by resveratrol: in vitro and in vivo studies and the underlying mechanisms (review) / M. H. Aziz, R. Kumar, N. Ahmad // Int. J. Oncol. 2003. - No. 23. - P. 17-28.

8. Сорока Ю. В. Сорбційна корекція змін імунологічної реактивності щурів за умов експериментального канцерогенезу та застосування хіміотерапевтичних чинників / Ю. В. Сорока // Світ біології та медицини. -2013 . - № 4. - С. 82-86.

9. Рыболовлев Ю. Р. Дозирование веществ для млекопитающих по константам биологической активности / Ю. Р. Рыболовлев, Р. С. Рыболовлев // Докл. AH CCCP. - 1979. - 247, № 6. - C. 1513-1516.

10. Whitfield J.B. Gamma glutamyl transferase / J. B. Whitfield // Crit. Rev. Clin. Lab. Sci. - 2001. № 38 (4). - P. 263-355. Review. PubMed PMID: 11563810 .

11. Камышников В. С. Справочник по клинико-биохимической лабораторной диагностике : в 2 т. I В. С. Камышников. - Минск : Беларусь, 2000. - Т. 1. 495 с. ; T. 2. -463 C.

12. Тогайбаев А. А. Метод определения эндогенной интоксикации / А. А. Тогайбаев, А. В. Кургузкин, И. В. Рикун // Лаб. дело. - 1988. - № 9. - С. 22-24.

13. Никольская В. А. Биохимический аспект рассмотрения роли молекул средней массы в организме / В. А. Никольская, Ю. Д. Данильченко, З. Н. Меметова // Ученые записки Таврического нац. ун-та им. В. И. Вернадского. Серия "Биология, химия". 2013. - № 1 (65). - С. 139-145.

\section{REFERENCES}

1. Mykhaylovych, Yu.Y., \& Zhurbenko, A.V., \& Sumkina, O.V. (2013). Praktychni aspekty vprovadzhennia skryninhu kolorektalnoho raku v Ukraini. Sotsialno-ekonomichne obhruntuvannia [Practical aspects of introduction of colorectal cancer screening in Ukraine. Socioeconomic substantiation]. Klynicheskaya onkologiya Clinical Oncology, 3, 6-10 [in Ukrainian].

2. Kuznyetsova, H.M. \& Lynchak, O.V., Danylov, M.O., Kotlyar, I.P., \& Rybalchenko, V.K. (2013). Vplyv pokhidnykh dyhidropirolu ta maleimidu na stan pechinky i tovstoi kyshky shchuriv u normi tav umovakh indukovanoho dymetylhidrazynom kolorektalnoho raku [The effect of dihydropyrrole and maleimide derivatives on the condition of the liver and colon of rats in normal and in conditions of dimethylhydrazine-induced colorectal cancer]. Ukr. biokhim. zhurn. - Ukr. Biochemistry Journal, 85(3), 74-84 [in Ukrainian].

3. Perse, M. \& Cerar, M. (2005). The dimethylhydrazine induced colorectal tumours in rat-experimental colorectal carcinogenesis. Oncol., 39, 1, 61-70.

4. Filinska, O.M. \& Yablonska, S.V., Lynchak, O.V., Burlaka, A.P., Ostrovska, H.V., Rybalchenko, T.V. (2010). Vplyv pokhidnoho maleimidu na rozvytok okysnoho stresu $\checkmark$ pechintsi pry indukovanomu 1,2-dymetylhidrazynom
14. Gross D. Ethics in Animal-Based Research / D. Gross, R. Tolba // Eur. Surg. Res. -2015. -55 (1-2). P. 43-57.

15. Okeh U. Statistical problems in medical research / U. Okeh // East. Afr. J. Public. Health. - 2009. 6 (1). - P. 1-7.

16. Баджинян С. А. Влияние оксидативного стресса на организм человека / С. А. Баджинян // Мед. наука Армении НАН РА. - 2016. - LVI, № 2. - С. 12-20.

17. Гривенникова В. Г. Генерация активных фрорм кислорода митохондриями / В. Г. Гривенникова, А. Д. Виноградов // Усп. биол. хим. - 2013. - № 53. C. $245-296$.

18. Мороз Л. В. Застосування препарату Ентеросгель у комплексній терапії пацієнтів із гострими вірусними гепатитами із супутнім дисбактеріозом кишечника / Л. В. Мороз, І. Г. Палій, Т. В. Ткаченко // Внутренняя медицина. - 2008. - № 1 (7). - С. 11-18.

19. Кулініч О. С. Модуляція гепатотоксичності цисплатину кластерними сполуками ренію (III) у моделі канцерогенезу / О. С. Кулініч, О.О.Дьомшина, Н. І. Штеменко // Мед. хімія. - 2013. - 15, № 3. C. 21-26.

20. Виткина Т. И. Средние молекулы в оценке уровня эндогенной интоксикации при хроническом необструктивном бронхите / Т. И. Виткина // Здоровье. Медицинская экология. Наука. - 2014. - № 56 (2). C. 70-72.

21. Карякина Е. В. Молекулы средней массы как интегральный показатель метаболических нарушений (обзор литературы) / Е. В. Карякина, С. В. Белова // Клинич. лаб. диагностика. - 2004. - № 3. - С. 3-8.

22. Матвеев С. Б. Оценка эндогенной интоксикации по показателям среднемолекулярных пептидов при неотложных состояниях / С. Б. Матвеев, Н. В. Федорова, М. А. Годков // Клинич. лаб. диагностика. 2009. - № 5. - C. 16-18.

kantserohenezi tovstoho kyshechnyka shchuriv [Influence of maleimide derivative on the development of oxidative stress in the liver in 1,2-dimethylhydrazine-induced carcinogenesis of the large intestine of rats]. Dopovidi Natsionalnoi akademii nauk Ukrainy - Reports of the National Academy of Sciences of Ukraine, 8, 185-190 [in Ukrainian].

5. Beijnen, J.H. \& Schellens, J.H (2004). Drug interactions in oncology. Lancet Oncol., 5 (8), 489-496.

6. Baur, J.A. \& Sinclair, D.A. (2006). Therapeutic potential of resveratrol: the in vivo evidence. Nat. Rev. Drug Discov., 5, 493-506.

7. Aziz, M.H. \& Kumar, R, Ahmad, N. (2003). Cancer chemoprevention by resveratrol: in vitro and in vivo studies and the underlying mechanisms (review). Int. J. Oncol., 23,17-28.

8. Soroka, Yu.V. (2013). Sorbtsiina korektsiia zmin imunolohichnoi reaktyvnosti shchuriv za umov eksperymentalnoho kantserohenezu ta zastosuvannia khimioterapevtychnykh chynnykiv [Sorption correction of changes in immunological reactivity of rats under conditions of experimental carcinogenesis and application of chemotherapeutic factors]. Svit biolohii ta medytsyny World of Biology and Medicine, 4, 82-86 [in Ukrainian]. 
9. Rybolovlev, Yu.R., \& Rybolovlev, R.S. (1979). Dozirovaniye veshchestv dlya mlekopitayushchikh po konstantam biologicheskoy aktivnosti [Dosing of substances for mammals according to the constants of biological activity]. Doklady AN SSSR - Reports of the USSR Academy of Sciences, 247, 6, 1513-1516 [in Russian].

10. Whitfield, J.B. (2001). Gamma glutamyl transferase Crit. Rev. Clin. Lab. Sci., 38(4), 263-355. Review. PubMed PMID: 11563810.

11. Kamyshnikov, V.S. (2000). Spravochnik po kliniko-biokhimicheskoy laboratornoy diagnostike: $\mathrm{v} 2-\mathrm{kh} \mathrm{t}$ [Handbook of clinical and biochemical laboratory diagnostics: in 2 volumes]. Minsk: Belarus - Minsk: Belarus, 1, 495-2, 463 [in Russian].

12. Togaybayev, A.A., Kurguzkin, A.V., \& Rikun, I.V. (1988). Metod opredeleniya endogennoy intoksikatsii [Method for determining endogenous intoxication]. Lab. Delo - Lab. Business, 9, 22-24 [in Russian].

13. Nikolskaya, V.A., Danilchenko, Yu.D., \& Memetova, Z.N. (2013). Biokhimicheskiy aspekt rassmotreniya roli molekul sredney massy $v$ organizme [Biochemical aspect of consideration of the role of average mass molecules in the body in the body]. Uchenyye zapiski Tavricheskogo natsionalnogo universiteta im. V.I. Vernadskogo Ser.: Biologiya, khimiya - Scientific Notes of Taurida National University. VI Vernadsky Ser.: Biology, Chemistry, 1 (65), 139-145 [in Ukrainian].

14. Gross, D. \& Tolba, R. (2015). Ethics in animalbased research. Eur. Surg. Res., 55(1-2), 43-57.

15. Okeh, U. (2009). Statistical problems in medical research. East. Afr. J. Public. Health, 6 (1), 1-7.

16. Badzhinyan, S.A. (2016) Vliyaniye oksidativnogo stressa na organizm cheloveka [Influence of oxidative stress on the human body]. Meditsinskaya nauka Armenii NAN RA - Medical Science of Armenia NAS RA, LVI(2), 12-20 [in Russian].

17. Grivennikova, V.G. \& Vinogradov, A.D. (2013). Generatsiya aktivnykh form kisloroda mitokhondriyami
[Generation of reactive oxygen species by mitochondria]. Usp. biol. khim - Suc. Biological Chem., 53, 245-296 [in Russian].

18. Moroz, L.V., \& Paliy, I.H., Tkachenko, T.V. (2008). Zastosuvannia preparatu Enteros hel u kompleksnii terapii patsiientiv iz hostrymy virusnymy hepatytamy iz suputnim dysbakteriozom kyshechnyka [Application of Enterosgel drug in complex therapy of patients with acute viral hepatitis with concomitant intestinal dysbacteriosis]. Vnutrennyaya medytsyna - Internal Medicine, 1 (7), 1118 [in Russian].

19. Kulinich, O.S., \& Domshyna, O.O., \& Shtemenko, N.I. (2013). Moduliatsiia hepatotoksychnosti tsysplatynu klasternymy spolukamy reniiu (III) u modeli kantserohenezu [Modulation of cisplatin hepatotoxicity by rhenium (III) cluster compounds in a carcinogenesis model]. Medychna khimiia - Medical Chemistry, 3, 21-26 [in Ukrainian].

20. Vitkina, T.I. (2014). Sredniye molekuly v otsenke urovnya endogennoy intoksikatsii pri khronicheskom neobstruktivnom bronkhite [Medium molecules in assessing the level of endogenous intoxication in chronic non-obstructive bronchitis]. Zdorovye. Meditsinskaya ekologiya. Nauka - Health. Medical Ecology. The Science, 56 (2), 70-72 [in Russian].

21. Karyakina, Ye.V. \& Belova, S.V. (2004). Molekuly sredney massy kakintegralnyy pokazatel metabolicheskikh narusheniy (obzor literatury) [Average mass molecules as an integral indicator of metabolic disorders (literature review)]. Klin. lab. diagnostika - Clin. Lab. Diagnostics, 3, 3-8 [in Ukrainian].

22. Matveyev, S.B., Fedorova, N.V., \& Godkov, M.A. (2009). Otsenka endogennoy intoksikatsii po pokazatelyam srednemolekulyarnykh peptidov pri neotlozhnykh sostoyaniyakh [Evaluation of endogenous intoxication by indicators of medium molecular peptides in emergency conditions]. Klin. lab. diagnostika - Clin. Lab. Diagnostics, 5, 16-18 [in Ukrainian].

О. Б. Рицик, Л. С. Фира, П. Г. Лихацкий

ТЕРНОПОЛЬСКИЙ НАЦИОНАЛЬНЫЙ МЕДИЦИНСКИЙ УНИВЕРСИТЕТ ИМЕНИ И. Я. ГОРБАЧЕВСКОГО МОЗ УКРАИНЫ

\section{РЕСВЕРАТРОЛ КАК СРЕДСТВО ЦИТОПРОТЕКТОРНОГО ДЕЙСТВИЯ ПРИ ИНДУЦИРОВАННОМ КАНЦЕРОГЕНЕЗЕ У КРЫС}

\section{Резюме}

Вступление. Важной фундаментальной задачей современных экспериментальных и клинических исследований в онкологии являются изучение существующих и выявление новых, в том числе метаболических, фракторов, способствующих возникновению и прогрессированию опухолевого процесса. Исследования in vitro u in vivo показали, что фритохимические вещества имеют потенциальные антиоксидантные, противовоспалительные и антиканцерогенные свойства. На сегодняшний день активно изучают механизмы противораковой активности ресвератрола - природного полифенола, который способен ингибировать пролиферацию большинства клеточных линий рака человека.

Цель исследования - изучить цитопротекторные свойства ресвератрола при индуцированном диметилгидразином онкопроцессе.

Методы исследования. Эксперименты выполнены на белых крысах-самцах, которым моделировали рак толстой кишки путем еженедельного подкожного введения диметилгидразина в дозе 7,2 мг/кг массы тела в течение 30 недель. Антиоксидант ресвератрол вводили интрагастрально в дозе 20 мг/кг еже- 
дневно на протяжении 7 месяцев. Состояние цитоплазматических клеточных мембран изучали по активности гамма-глутамилтранспептидазы и щелочной фросфратазы. Степень эндотоксемии оценивали путем определения эритроцитарного индекса интоксикации и содержания молекул средней массы.

Результаты и обсуждение. После введения крысам диметилаидразина наблюдали повышение в сыворотке крови активности гамма-глутамилтранспептидазы и щелочной фросфратазы во все сроки исследования, а также ее снижение в печени животных с канцерогенезом. На фроне ежедневного применения ресвератрола активность гамма-глутамилтранспептидазы уменьшилась в 2 раза, щелочной оросфратазы - в 2,3 раза по отношению к животным, которым вводили диметилаидразин. У крыс, получавших антиоксидант ресвератрол, проницаемость эритроцитарной мембраны уменьшилась на 50,7\% по сравнению с животными, которые его не получали. Использование ресвератрола привело к уменьшению в сыворотке крови содержания молекул средней массы всех фракций, что указывает на снижение проявлений эндогенной интоксикации в пораженном организме.

Выводы. Полученные результаты подтверждают цитопротекторные свойства ресвератрола, на которые указывает восстановление активности мембранозависимых энзимов у крыс с экспериментальным канцерогенезом. Доказано, что в этих условиях профилактическое применение ресвератрола снижает уровень эндогенной интоксикации и способствует восстановлению проницаемости эритроцитарных мембран, что подтверждает его мембранопротекторные свойства.

КЛЮЧЕВЫЕ СЛОВА: цитолитические процессы; эндогенная интоксикация; проницаемость клеточных мембран; ресвератрол.

O. B. Rytsyk, L. S. Fira, P. H. Lykhatskyi I. HORBACHEVSKY TERNOPIL NATIONAL MEDICAL UNIVERSITY

\section{RESVERATROL AS A CYTOPROTECTIVE ACTION FOR INDUCED CARCINOGENESIS IN RATS}

\section{Summary}

Introduction. An important, fundamental task of modern experimental and clinical research in oncology is the study of existing and identification of new ones, including metabolic factors that contribute to the emergence and progression of the tumor process. In vitro and in vivo studies have shown that phytochemicals have potential antioxidant, anti-inflammatory and anti-carcinogenic properties. To date, the mechanisms of the anticancer activity of resveratrol, a natural polyphenol that has the ability to inhibit the proliferation of most human cancer cell lines, are being actively studied.

The aim of the study - to investigate the cytoprotective properties of resveratrol under conditions of dimethylhydrazine-induced oncological process.

Research Methods. The experiments were performed on male white rats, which were simulated for colon cancer by weekly subcutaneous administration of 1,2-dimethylhydrazine at a dose of $7.2 \mathrm{mg} / \mathrm{kg}$ of body weight for 30 weeks. The antioxidant resveratrol was administered intragastrically at a dose of $20 \mathrm{mg} / \mathrm{kg}$ daily for 7 months. The state of cytoplasmic cell membranes was studied by the activity of gamma-glutamyltranspeptidase and alkaline phosphatase. The degree of endotoxemia was assessed by determining the erythrocyte index of intoxication and the content of average weight molecules.

Results and Discussion. After administration of dimethylhydrazine to animals, an increase in the activity of gamma-glutamyltranspeptidase and alkaline phosphatase in the blood plasma was observed in all periods of the study, as well as their decrease in the liver of animals with carcinogenesis. Against the background of daily use of resveratrol, the activity of gamma-glutamyltranspeptidase decreased by 2 times, alkaline phosphatase by 2.3 times in relation to animals that were injected with dimethylhydrazine. In animals that received the antioxidant resveratrol, the permeability of the erythrocyte membrane decreased by $50.7 \%$ compared with animals that did not receive it. The use of resveratrol led to a decrease in the content of molecules of the average mass of all fractions in the blood serum, which indicates a decrease in the manifestations of endogenous intoxication in the affected organism.

Conclusions. The results obtained confirm the cytoprotective properties of resveratrol, which are indicated by the restoration of the activity of membrane-dependent enzymes in rats with experimental carcinogenesis. It has been shown that under these conditions, the prophylactic use of resveratrol reduces the level of endogenous intoxication and helps to restore the permeability of erythrocyte membranes, which confirms its membrane-protective properties.

KEY WORDS: cytolytic processes; endogenous intoxication; permeability of cell membranes; resveratrol.

Отримано 10.02.21

Адреса для листування: Л. С. Фіра, Тернопільський національний медичний університет імені І. Я. Горбачевського мОз України майдан Волі, 1, Тернопіль, 46001, Україна, e-mail: firals@tdmu.edu.ua. 